\title{
Anti-SARS-CoV-2 IgG responses are powerful predicting signatures for the outcome of COVID-19 patients
}

Qing Lei ${ }^{1,+}$, Cai-zheng $\mathrm{Yu}^{2,+}$, Yang $\mathrm{Li}^{3,+}$, Hong-yan Hou ${ }^{4}$, Zhao-wei Xu ${ }^{3}$, Zong-jie Yao ${ }^{1}$, Yan-di Zhang $^{1}$, Dan-yun Lai ${ }^{3}$, Jo-Lewis Banga Ndzouboukou ${ }^{1}$, Bo Zhang ${ }^{4}$, Hong Chen ${ }^{3}$, Zhu-qing Ouyang ${ }^{1}$, Jun-biao Xue ${ }^{3}$, Xiao-song Lin ${ }^{1}$, Yun-xiao Zheng ${ }^{3}$, Xue-ning Wang ${ }^{3}$, He-wei Jiang ${ }^{3}$, Hai-nan Zhang ${ }^{3}$, Huan $\mathrm{Qi}^{3}$, Shu-juan $\mathrm{Guo}^{3}$, Mei-an $\mathrm{He}^{5}$, Zi-yong Sun ${ }^{4}$, Feng Wang ${ }^{4, *}$, Sheng-ce Tao ${ }^{3, *}$, Xiong-lin $\operatorname{Fan}^{1, *}$

${ }^{1}$ Department of Pathogen Biology, School of Basic Medicine, Tongji Medical College, Huazhong University of Science and Technology, Wuhan, China

${ }^{2}$ Department of Public Health, Tongji Hospital, Tongji Medical College, Huazhong University of Science and Technology, Wuhan, China

${ }^{3}$ Shanghai Center for Systems Biomedicine, Key Laboratory of Systems Biomedicine (Ministry of Education), Shanghai Jiao Tong University, Shanghai 200240, China

${ }^{4}$ Department of Laboratory Medicine, Tongji Hospital, Tongji Medical College, Huazhong University of Science and Technology, Wuhan, China.

${ }^{5}$ Department of Occupational and Environmental Health and State Key Laboratory of Environmental and Health for Incubating, School of Public Health, Tongji Medical College, Huazhong University of Science and Technology, Wuhan, China.

${ }^{+}$These authors contributed equally to this paper.

*Corresponding authors: Xiong-lin Fan (xlfan@hust.edu.cn), Sheng-ce Tao (taosc@sjtu.edu.cn), Feng Wang (wangfeng@tith.tjmu.edu.cn). 
medRxiv preprint doi: https://doi.org/10.1101/2020.11.10.20228890; this version posted May 8, 2021. The copyright holder for this preprint (which was not certified by peer review) is the author/funder, who has granted medRxiv a license to display the preprint in perpetuity.

All rights reserved. No reuse allowed without permission.

\begin{abstract}
The COVID-19 global pandemic is far from ending. There is an urgent need to identify applicable biomarkers for early predicting the outcome of COVID-19. Growing evidences have revealed that SARS-CoV-2 specific antibodies evolved with disease progression and severity in COIVD-19 patients. We assumed that antibodies may serve as biomarkers for predicting disease outcome. By taking advantage of a newly developed SARS-CoV-2 proteome microarray, we surveyed IgG responses against 20 proteins of SARS-CoV-2 in 1,034 hospitalized COVID-19 patients on admission and followed till 66 days. The microarray results were further correlated with clinical information, laboratory test results and patient outcomes. Cox proportional hazards model was used to explore the association between SARS-CoV-2 specific antibodies and COVID-19 mortality. We found that nonsurvivors induced higher levels of $\mathrm{IgG}$ responses against most of non-structural proteins than survivors on admission. In particular, the magnitude of $\operatorname{IgG}$ antibodies against 8 nonstructural proteins (NSP1, NSP4, NSP7, NSP8, NSP9, NSP10, RdRp, and NSP14) and 2 accessory proteins (ORF3b and ORF9b) possessed significant predictive power for patient death, even after further adjustments for demographics, comorbidities, and common laboratory biomarkers for disease severity (all with $p$ trend $<0.05$ ). Additionally, $\operatorname{IgG}$ responses to all of these 10 nonstructural/accessory proteins were also associated with the severity of disease, and differential kinetics and serum positive rate of these IgG responses were confirmed in COVID-19 patients of varying severities within 20 days after symptoms onset. The AUCs for these IgG responses, determined by computational cross-validations, were between 0.62 and 0.71 . Our findings have important implications for improving clinical management, and especially for developing medical interventions and vaccines.
\end{abstract}

\title{
Keywords
}

COVID-19, SARS-CoV-2, predicting signature, IgG, non-structural/accessory protein, outcome 
medRxiv preprint doi: https://doi.org/10.1101/2020.11.10.20228890; this version posted May 8, 2021. The copyright holder for this preprint (which was not certified by peer review) is the author/funder, who has granted medRxiv a license to display the preprint in perpetuity.

All rights reserved. No reuse allowed without permission.

\section{Introduction}

The coronavirus disease 2019 (COVID-19), the emerging infectious disease caused by severe acute respiratory syndrome coronavirus 2 (SARS-CoV-2) in December 2019, has quickly become the greatest crisis of global public health, social and economic developments in our times ${ }^{1}$. As of April 25, 2021, there has been 146.05 million confirmed cases and 3.09 million patients death from SARSCoV-2 infection worldwide ${ }^{2}$. Currently, there are no highly effective therapeutics available for the COVID-19 patients ${ }^{3-5}$. Data from Phase III clinical trials showed that the protective efficacy of vaccines, namely, mRNA-1273 ${ }^{6}$, BNT162b2 mRNA $^{7}$, and ChAdOx $1 \mathrm{nCoV}-19$ (AZD1222) ${ }^{8}$ based on the spike protein of the virus were $94.5 \%, 95.0 \%$ and $70.4 \%$, respectively. However, several vaccinators developed severe allergic symptoms after vaccination ${ }^{9,10}$, which may belong to vaccinerelated immunopathological phenomena though antibody-dependent enhancement (ADE) mechanism ${ }^{11,12}$. Therefore, it is of significance to elucidate the role of host immune responses in clinical progression and outcome of COVID-19 patients for improving clinical management and developing more effective interventions.

Similar to SARS-CoV and MERS-CoV, SARS-CoV-2 belongs to the beta-coronavirus genus and its genome encodes four major structural proteins, namely, spike (S), envelope (E), membrane (M), and nucleocapsid $(\mathrm{N})$, and 15 non-structural proteins (Nsp1-10 and Nsp12-16), and 8 accessory proteins ${ }^{13}$. Among these, the $\mathrm{S}$ protein, consisted of $\mathrm{N}$-terminal $\mathrm{S} 1$ peptide with an important receptor binding domain (RBD) and C-terminal S2 fragment, plays an essential role in viral attachment, fusion, and entry into the target cells which express the viral receptor angiotensinconverting enzyme 2 (ACE2) ${ }^{14}$. There has been rapidly growing serological evidence that IgM, IgG, and IgA antibodies against $\mathrm{S}$ or $\mathrm{N}$ proteins of SARS-CoV-2 evolve rapidly in the serum of both asympomatic and symptomatic COVID-19 infections within one week after infection or onset of symptoms ${ }^{15-18}$. Moreover, these antibodies elevated with disease progression and severity in symptomatic COIVD-19 patients ${ }^{19}$. Therefore, anti-SARS-CoV-2 specific antibodies may involve in the pathogenesis and affect the disease progression.

In this study, we assumed that levels of anti-SARS-CoV-2 IgG antibodies might help predict the prognosis and outcome of patients with COVID-19. Proteome microarray technology has been confirmed as a mature and repeatable assay, which has been widely used in serological analysis of various diseases ${ }^{20-22}$. To enable the global understanding of SARS-CoV-2 specific IgG responses and their application, we constructed a proteome microarray with 20 out of the 28 predicted proteins of SARS-CoV-2 ${ }^{18,23}$. Clinical serum specimens were analyzed on the SARS-CoV-2 proteome microarray, which can provide a high-throughput assay for 12 samples on each microarray and a rapid turnaround time of assay results (within $5 \mathrm{~h}$ after sample collection).

1,034 patients hospitalized for confirmed COVID-19 disease at Tongji hospital from the day of hospitalization to the day of discharge or death were enrolled in this study. Serum IgG profiles for 
medRxiv preprint doi: https://doi.org/10.1101/2020.11.10.20228890; this version posted May 8, 2021. The copyright holder for this preprint (which was not certified by peer review) is the author/funder, who has granted medRxiv a license to display the preprint in perpetuity.

All rights reserved. No reuse allowed without permission.

1,034 patients with COVID-19 on admission were probed using the SARS-CoV-2 proteome microarray. The microarray results were further correlated with laboratory biomarkers of disease severity and comorbidities, and with death of each patients, whose known clinical outcomes collected from electronic medical records. We found that the magnitude IgG responses to most of non-structural/accessory proteins were powerful predicting signatures for the COVID-19 death, , independent of other biomarkers of laboratory and clinical severity factors.

\section{Materials}

\section{Patient information and data source}

1,056 confirmed COVID-19 patients were recruited from Tongji Hospital, Wuhan, China, between 17 February 2020 and 28 April 2020. COVID-19 was diagnosed based on positive SARS-CoV-2 nucleic acid test from respiratory tract specimens or based on clinical diagnosis with clinical symptoms and imaging features of pneumonia on chest computed tomographic (CT) according to the fifth version of COVID-19 diagnostic and treatment guideline, published by the National Health Commission of China (NHCC) ${ }^{24}$. Demographic information, medical history, comorbidities, signs and symptoms, chest $\mathrm{CT}$, laboratory findings during hospitalization, and clinical outcomes were collected from electronic medical records. Among these, laboratory biomarkers related with disease severity factors such as the blood routine (leucocytes, lymphocytes, platelets, and neutrophils), liver and kidney functions (aspartate aminotransferase, alanine aminotransferase, lactate dehydrogenase, and creatinine), coagulation function (D-dimer) and inflammatory biomarkers (C-reactive protein, procalcitonin) were performed by automated analyzers according to the manufacturers' instructions. The level of IL-2R in serum was measured by an automatic solid-phase two-site chemiluminescent immunometric assay via IMMULITE 1000 Analyzer (Siemens, Germany). Serum IL-6 was measured by an electro-chemiluminescence method (Roche Diagnostics, Switzerland).

Serum specimens were collected from each patient on admission and were stored at $-80^{\circ} \mathrm{C}$ until use. Serum detection based on proteome microarray and data analysis were performed during April 2020 to March 2021. After excluding 22 individuals whose anti-SARS-CoV-2 antibody indicators were missing more than three, a total of 1,034 eligible participants (524 females and 510 males) with available data from serum proteome microarray and their clinical outcomes were used for the final analysis. Among 1,034 eligible participants, some of whom had serial serum samples and were collected for a total of 2,977 samples.

\section{Ethical approval}

The study was approved by the Ethical Committee of Tongji Hospital, Tongji Medical College, Huazhong University of Science and Technology, Wuhan, China (IRB ID:TJ-C20200128).

\section{Protein microarray fabrication}


medRxiv preprint doi: https://doi.org/10.1101/2020.11.10.20228890; this version posted May 8, 2021. The copyright holder for this preprint (which was not certified by peer review) is the author/funder, who has granted medRxiv a license to display the preprint in perpetuity.

All rights reserved. No reuse allowed without permission.

The microarray used for serum IgG profiling was prepared as described previously ${ }^{18,23} .20$ proteins of SARS-CoV-2 with indicated concentrations, along with the negative (GST, Biotin-control, and eGFP) and positive controls (Human IgG and ACE2-Fc), were printed in quadruplicate on PATH substrate slide (Grace Bio-Labs, USA) to generate identical arrays in a $2 \times 7$ subarray format using Super Marathon printer (Arrayjet, UK). The prepared protein microarrays were incubated in blocking buffer ( $3 \%$ BSA in $1 \times$ PBS buffer with $0.1 \%$ Tween 20 ) for $3 \mathrm{~h}$, and then stored at $-80{ }^{\circ} \mathrm{C}$ until use.

\section{Microarray-based serum analysis}

The protein microarrays stored at $-80{ }^{\circ} \mathrm{C}$ were warmed to room temperature before detection and were performed to probe all available seral samples. A 14-chamber rubber gasket was mounted onto each slide to create individual chambers for the 14 identical subarrays. Serum samples were diluted 1:200 in PBS containing 0.1\% Tween 20 and a total of $200 \mu \mathrm{L}$ of diluted serum or buffer only (negative controls) was incubated with each subarray for $2 \mathrm{~h}$ at $4^{\circ} \mathrm{C}$. The arrays were washed with $1 \times$ PBST and bound antibodies were detected by incubating with Cy3-conjugated goat anti-human IgG (Jackson ImmunoResearch, USA), which were diluted 1: 1,000 in 1×PBST, and incubated at room temperature for $1 \mathrm{~h}$. The microarrays were then washed with $1 \times \mathrm{PBST}$ and dried by centrifugation at room temperature and scanned by LuxScan 10K-A (CapitalBio, China) with the parameters set as 95\% laser power/ PMT 480 for IgG. Data of fluorescent intensity (FI) from each microarray was extracted by GenePix Pro 6.0 software (Molecular Devices, USA). The result of FI for each serum response to each protein was defined as the median of the foreground subtracted by the median of background for each spot and then averaged the triplicate spots for each protein. The result of the protein-specific antibody in the serum was expressed as $\log _{2}(\mathrm{FI})$.

\section{Statistical analysis}

Shapiro-Wilk test was used to test data normality. Two-tailed t-test was conducted to test difference in means between survivor and nonsurvivor groups, Mann-Whitney U test was performed to test difference in skewed parameters. Chi-square tests or Fisher's exact test, when appropriate, was used for categorical variables. Cox proportional-hazards model was performed to estimate the hazard ratios (HRs) and 95\% confidence intervals (CIs) of COVID-19 mortality for individual levels of virus-specific IgG responses categorized into tertiles according to distributions. The lowest tertiles were assigned to be the reference groups. Age and sex were included in Model 1. In Model 2, we further adjusted hypertension (yes/no), diabetes (yes/no), lymphopenia $\left(<1.1, \geq 1.1, \times 10^{\wedge} 9 / \mathrm{L}\right.$ ), increased alanine aminotransferase $(<40, \geq 41, \mathrm{U} / \mathrm{L})$, and increased lactate dehydrogenase $(<214$, $\geq 214, \mathrm{U} / \mathrm{L}$ ). Linear trend $p$-values were calculated by modeling the median value of each antibody tertiles as a continuous variable in the adjusted models. Spearman's rank correlation analysis was performed to explore the correlations between virus-specific IgG responses and laboratory results in the study population. The principal component analysis (PCA) based on the 20 proteins of SARS- 
medRxiv preprint doi: https://doi.org/10.1101/2020.11.10.20228890; this version posted May 8, 2021. The copyright holder for this preprint (which was not certified by peer review) is the author/funder, who has granted medRxiv a license to display the preprint in perpetuity.

All rights reserved. No reuse allowed without permission.

CoV-2 specific IgG responses was used to optimize the type of data and extract principal components (PCs). SARS-CoV-2 protein -specific IgG responses with factor loadings over 0.7 on a particular PC were regarded as main contributors of it. Each PC was modeled into the Cox proportional-hazards models as tertiles to evaluate the association with anti-SARS-CoV-2 specific $\operatorname{IgG}$ responses and the COVID-19 mortality.

In addition, the results of antibodies were classified as two groups of the high levels ( $\geq$ median) and low levels ( $<$ median) based on the medians of IgG responses to each protein and further correlated these results with on day 66 mortality of all involved COVID-19 patients by Kaplan-Meier survival curve and log-rank test. Loess regression was used to establish the kinetics of SARS-CoV-2 specific antibodies. Cluster analysis was performed with pheatmap package of R. SAS (version 9.4), R (version 4.0.0), and SPSS (version 23.0) were used to conduct statistical analysis when applicably used. Two-sided statistical tests were considered to be significant at a $p$ value below 0.05 .

\section{Computational cross-validations of the prediction efficacy for clinical outcome}

The receiver operating characteristic curve was conducted for the prediction of COVID-19 survival and death, and 1,000 times computational cross-validations were conducted. For each crossvalidation procedure, 477 survivors and 39 nonsurvivors were randomly selected as the training set. The rest of the samples were treated as the testing set (478 survivors and 40 nonsurvivors).

\section{Results}

\section{Characteristics of the study population}

1,034 participants, having available serum microarray results and consisting of 955 survivors and 79 nonsurvivors, were enrolled in this study. Baseline characteristics of participated patients based on electronic medical records were analyzed as Table 1. The median age of all enrolled patients was 63 years old (IQR, 51-71). The median intervals from onset of symptoms to hospital admission, from onset of symptoms to recovery, and from onset of symptoms to death were 13 days (IQR, 821), 41 days (IQR, 33-52), and 32 days (IQR, 25-39), respectively. The median length of all COVID19 patients' hospital stay was 24 days (IQR, 15-35). 37\% patients with COVID-19 had hypertension and $18.5 \%$ with diabetes. $30.7 \%$ patients had lymphopenia, while increased levels of lactate dehydrogenase and alanine aminotransferase were detected in $43 \%$ and $25.4 \%$ patients, respectively. Consistent with previous reports ${ }^{25,26}$, nonsurvivors were more likely to be male, and older than survivors $(p<0.001)$. Higher proportion of abnormal laboratory results and shorter hospitalization time were observed in nonsurvivors than those of survivors $(p<0.001)$.

\section{Nonsurvivors produce higher levels of IgG responses against most of non-structural proteins than survivors}

To establish the association of anti-SARS-CoV-2 IgG antibodies with COVID-19 survival and death, 
serum collected from each involved patients on admission was used for microarray-based serum analysis. Based on the FI value extracted from the proteome microarray for each serum sample of 1034 patients, we first compared IgG profiles against 20 proteins of SARS-CoV-2 (Table 2). There was no statistical difference of the levels of either anti-S or N IgG antibodies between nonsurvivors and survivors. However, higher levels of IgG responses against 15 proteins, namely, E, NSP1, NSP2, NSP4, NSP5, NSP7, NSP8, NSP9, NSP10, RdRp, NSP14, NSP15, NSP16, ORF3b and ORF9b, were induced in nonsurvivors than those of survivors. Our results indicate that the magnitude of $\operatorname{IgG}$ responses against most of non-structural proteins of SARS-CoV-2 might predict the prognosis and outcome of COVID-19.

\section{IgG responses against 10 non-structural/accessory proteins positively correlate with COVID-} 19 mortality risk

To assess the relationship of the magnitude of IgG antibodies with the mortality risk of COVID-19 patients, the HRs ( $95 \%$ CIs) for the mortality risk associated with the levels of IgG responses against different proteins of SARS-CoV-2 were categorized into tertiles (Table 3). We first analyzed the effects of age and gender on the disease death as model 1. After adjusting for age and gender, we found that IgG responses to 10 proteins (NSP1, NSP4, NSP7, NSP8, NSP9, NSP10, RdRp, NSP14, ORF3b and ORF9b) were significantly positively associated with the COVID-19 mortality, whereas negative significant association was observed between N, ORF3a, and ORF7b- specific IgG responses and the death. Previous studies reported that comorbidities and laboratory biomarkers related with the function of important organs also might be the risk factors of the COVID-19 death 26,27. Therefore, we further adjusted the association for hypertension, diabetes, lymphopenia, increased alanine aminotransferase and lactate dehydrogenase as shown in model 2. Interestingly, IgG responses to 10 proteins (NSP1, NSP4, NSP7, NSP8, NSP9, NSP10, RdRp, NSP14, ORF3b and ORF9b) were also significantly positively associated with the mortality risk of COVID-19 (Table 3).

The Kaplan-Meier survival curve also supported that COVID-19 patients with higher levels of specific IgG responses against NSP1 $\left(\log _{2} \mathrm{FI} \geq 8.2\right)$, NSP4 ( $\left.\log _{2} \mathrm{FI} \geq 7.9\right), \mathrm{NSP} 7\left(\log _{2} \mathrm{FI} \geq 9.4\right)$, NSP8 ( $\left.\log _{2} \mathrm{FI} \geq 7.8\right), \mathrm{NSP} 9\left(\log _{2} \mathrm{FI} \geq 8.7\right), \mathrm{NSP} 10\left(\log _{2} \mathrm{FI} \geq 6.3\right), \mathrm{RdRp}\left(\log _{2} \mathrm{FI} \geq 8.1\right), \mathrm{NSP} 14\left(\log _{2} \mathrm{FI} \geq\right.$ 7.4), ORF3b ( $\left.\log _{2} \mathrm{FI} \geq 8.7\right)$, and $\mathrm{ORF} 9 \mathrm{~b}\left(\log _{2} \mathrm{FI} \geq 8.0\right)$ had higher morality risk after admission, respectively (Figure 1).

To further establish the association among $\operatorname{IgG}$ responses to different proteins with the outcome of COVID-19, we further conducted principal component analyses (PCs) and screened hypothetical new variables that account for the variance as much as possible, in order to reduce the dimension of data and the complexity of data with the least loss of original information. The HRs (95\%CIs) for the COVID-19 mortality according to PCs tertiles were presented in Table 4. Four PCs with eigenvalues $>1$ were extracted, accounting for $71.95 \%$ of the total variance. Of four PCs, we found 
medRxiv preprint doi: https://doi.org/10.1101/2020.11.10.20228890; this version posted May 8, 2021. The copyright holder for this preprint (which was not certified by peer review) is the author/funder, who has granted medRxiv a license to display the preprint in perpetuity.

All rights reserved. No reuse allowed without permission.

that only PC1 had the statistical association with the COVID-19 mortality ( $p$ trend $=0.004$, Table 4), whatever adjusting age and sex, or further for hypertension, diabetes, lymphopenia, increased alanine aminotransferase and lactate dehydrogenase. Interestingly, IgG responses to 10 proteins (NSP1, NSP4, NSP7, NSP8, NSP9, NSP10, RdRp, NSP14, ORF3b and ORF9b) remained main contributors of PC1 (Table 5), in line with our above findings.

In addition, previous studies have established the associations between COVID-19 death with several laboratory measurements, such as lymphocyte count, procalcitonin, C-reactive protein, lactate dehydrogenase, D-dimer, IL-2R, and IL-6 ${ }^{25-27}$. Linear correlation between SARS-CoV-2 specific IgG responses with these biomarkers was further analyzed (Table 6). Interestingly, IgG responses to 10 proteins were positively correlated with most of these biomarkers but negatively associated with the lymphocyte count. Taken together, our results confirmed that IgG responses to 10 non-structural/accessory proteins were positively correlated with the mortality risk of COVID19.

IgG responses against 10 non-structural/accessory proteins are associated with the severity of COVID-19 disease

To assess the role of $\operatorname{IgG}$ to 10 non-structural/accessory proteins for the prediction of the clinical outcome, signal intensities and serum positive rates of $\mathrm{IgG}$ antibodies against 10 nonstructural/accessory proteins in 1,034 COVID-19 patients were compared with those of 601 healthy human serum controls. The cut-off value was set as mean $+2 \mathrm{SD}$ of the control group, and positive rates was calculated for each protein. Interestingly, COVID-19 patients had stronger signal intensities of serum IgG responses to all of these 10 proteins than healthy controls (Figure 2). In addition, the serum positive rates of IgG antibodies in COVID-19 patients ranged from $7.0 \%$ to $50.6 \%$, varying with different proteins. ORF3b, NSP7, and NSP1 specific IgG antibodies listed the top three of the serum positive rates in COVID-19 patients (Figure 2).

To further explore the association of IgG antibodies with the severity of illness, 1,034 COVID-19 patients included in this study were divided into three groups: non-severe $(\mathrm{n}=508)$, severe-survivors $(\mathrm{n}=447)$, and severe-nonsurvivors $(\mathrm{n}=79)$. Both the serum positive rate and the signal intensity of IgG responses were compared among these groups (Figure 3). Interestingly, severe-nonsurvivors had higher serum positive rates of NSP1, NSP7, NSP8, RdRp, ORF3b and ORF9b specific IgG antibodies than severe-survivors and the non-severe group. In addition, the overall signal intensities for the 10 protein-specific IgG antibodies were higher in severe-nonsurvivors than those of severesurvivors (Figure 3). These results suggested that the IgG responses of 10 non-structural/accessory proteins were also associated with the disease severity and might be effective predictors of disease prognosis.

\section{IgG responses to 10 non-structural/accessory proteins peak within 20 days after onset}


medRxiv preprint doi: https://doi.org/10.1101/2020.11.10.20228890; this version posted May 8, 2021. The copyright holder for this preprint (which was not certified by peer review) is the author/funder, who has granted medRxiv a license to display the preprint in perpetuity.

All rights reserved. No reuse allowed without permission.

To explore the detection time of IgG responses for the prediction, we further established the dynamic of IgG responses to 10 non-structural/accessory proteins from 0 to 60 days after onset, using 2,977 seral samples from 1,034 COVID-19 patients. Overall, the signal intensity and serum positive rate of the 10 protein-specific IgG antibodies increased persistently with the time after the symptom onset, peaked about 20 days later, and then declined gradually (Figure 4). Interestingly, severenonsurvivors had a stronger signal intensity and higher serum positive rate than non-severe and severe-survivors. Our results indicated that detection of these antibodies within 20 days after the symptom onset might be used to predict the prognosis of disease.

\section{Validation models confirm high prediction efficacy of IgG antibodies for clinical outcome}

It is a common practice to validate "potential biomarker" by independent sample cohort. However, it is very difficult to collect new COVID-19 serum samples in China. To assure the reliability of our finding, we performed computational cross-validation based on the large sample cohort, by following protocols as established previously ${ }^{21}$. IgG response to proteins (NSP1, NSP4, NSP7, NSP8, NSP9, NSP10, RdRp, NSP14, ORF3b and ORF9b) were explored as 10 potential biomarkers for predicting clinical outcome as shown in Figure 5. Interestingly, the AUCs of these $\operatorname{IgG}$ antibodies for predicting COVID-19 death ranged from 0.62 and 0.71 (Figure 6). NSP7, RdRp, and NSP14 specific IgG listed the top three of high AUC values.

\section{Discussion}

In this study, we demonstrated that IgG responses to 10 non-structural/accessory, namely, NSP1, NSP4, NSP7, NSP8, NSP9, NSP10, RdRp, NSP14, ORF3b, and ORF9b of SARS-CoV-2 were significantly positively associated with the mortality risk and disease severity of COVID-19, which are powerful predicting signatures for predicting clinical outcome. Our findings have important indications for medical interventions and better control of the COVID-19 pandemic.

Firstly, we established a rapid and high-throughput assay platform based on proteome microarrays to measure IgG responses against 20 SARS-CoV-2 proteins in the serum of COVID-19 patients. After analyzing 1,034 hospitalized patients, we found that the outcome of COVID-19 is associated with high levels of IgG responses to 10 non-structural/accessory proteins of SARS-CoV-2 at presentation. Importantly, our observations indicated that antibody patterns are predictive of COVID-19 mortality, independently of demographics and comorbidities, as well as routine clinical biomarkers of disease severity. In particular, we found that $\operatorname{IgG}$ antibodies against 8 non-structural proteins (NSP1, NSP4, NSP7, NSP8, NSP9, NSP10, RdRp, and NSP14) and 2 accessory proteins (ORF3b and ORF9b) were predictors of death after adjusting for the demographic features and comorbidities. Early IgG antibody measurements based on our established serum proteome microarray analysis as predictors of mortality, therefore, raise the importance of using antibody 
levels for rapidly improving clinical management, treatment decisions and rational allocation of medical resources in short supply during the process of dealing with the COVID-19 pandemic.

Although the function of each non-structural/accessory proteins of the SARS-CoV-2 is not yet fully understood, their protein sequences are highly similar to those of SARS-CoV. Most non-structural proteins always locate in the core of virion and play important roles in the pathogenesis. For example, RdRp, also called NSP12 of SARS-CoV, can catalyze the synthesis of viral RNA and plays an important role in the replication and transcription cycle of the virus ${ }^{28,29}$. RdRp itself performs the polymerase reaction with limited efficiency, whereas NSP7 and NSP8 as co-factors can significantly stimulate its polymerase activity ${ }^{28}$. Previous studies based on cryogenic electron microscopy (cryoEM) indicated that the viral polymerase (RdRp-NSP7-NSP8 complex) might be excellent targets for developing new therapeutics of SARS and COVID-19 ${ }^{29,30}$. NSP1 of the SARS-CoV may promote viral gene expression and immune escape by affecting interferon-mediated signal transduction ${ }^{31}$. NSP4 is a multichannel membrane protein, which is an essential protein for viral replication ${ }^{32}$. NSP9 plays a role of dimeric ssRNA binding protein during viral replication ${ }^{33,34}$. NSP10 interacts with NSP14 and regulates ribose-2'-O-MTase activities involved in mRNA capping ${ }^{34-36}$. In this study, we also found that IgG antibodies to non-structural/accessory proteins were positively correlated with routine clinical biomarkers of disease severity (procalcitonin, C-reactive protein, lactate dehydrogenase, D-dimer, IL-2R, and IL-6), but negatively correlated with the lymphocyte count. Therefore, nonsurvivors might result in more deaths of virus-infected cells and larger release of viral components from the dying cells than survivors, especially within 20 days after the symptom onset. Consequently, fuller interaction between viral non-structural/accessory proteins and the immune system of nonsurvivors resulted in stronger IgG responses to these proteins as evidenced in this study, which might underline the scientific background of these $\operatorname{IgG}$ responses as predicting signatures for the clinical outcome.

Moreover, some studies reported that treatment of COVID-19 patients with convalescent plasma was effective ${ }^{37,38}$, whereas others did not observe the positive results ${ }^{39,40}$. Several patients developed chills, rashes, shortness of breath, cyanosis, and severe dyspnea after treatment with convalescent plasma ${ }^{41}$, which might attribute to the ADE. There are two distinct mechanisms of ADE occurrence during viral infections: (1) enhanced antibody-mediated virus uptake into Fc $\gamma$ receptor IIa-expressing phagocytic cells thus leading to increased viral infection and replication; (2) excessive antibody Fc-mediated effector functions or immune complex formation causing enhanced inflammation and immunopathology ${ }^{11}$. IgG antibodies against these non-structural proteins and accessory proteins might play important roles in the ADE during SAS-CoV-2 infections. To mitigate the potential risks of $\mathrm{ADE}$ with convalescent plasma therapy, plasma donors should be purified from donated convalescent plasma to enrich for neutralizing antibodies or monitor the levels of these IgG antibodies and to avoid the risks of ADE caused by non-neutralizing antibodies against these nonstructural proteins. Currently, most of the COVID-19 subunit vaccines, such as mRNA-1273 and 
BNT162b2, are designed based on the S protein. In the present study, S1 specific IgG response is not a suitable predictor of the risk of COVID-19 mortality, which indicates the safety of these vaccines and is supported by the results of phase III clinical trials ${ }^{6,7}$.

In conclusion, we provided a novel application of SARS-CoV-2 proteome microarray to detect serum IgG responses for early predicting COVID-19 death. Our results demonstrate that high level of IgG responses against 8 non-structural proteins and 2 accessory proteins on admission increased the COVID-19 mortality risk. Our research might improve clinical management and guide the development of effective medical interventions and vaccines by deeply understanding of the pathogenesis of COVID-19.

\section{Acknowledgments}

We thank Prof. H. Eric Xu (Shanghai Institute of Materia Medica) for providing RdRp protein. We also thank Healthcode Co., Ltd., Hangzhou Bioeast biotech Co., Ltd. and Vacure Biotechnology Co.,Ltd. for providing the proteins.

\section{Author Contributors}

X-L.F., S-C.T., and F.W. performed experiments and designed the study. Q.L., C-Z.Y., and Y.L. performed the experiments. H-Y.H., Z-Y.S., and B.Z. collect specimens. D-Y.L., J-B.X., Z-Q.O., JL.B., and Z-W.X. prepared the reagents. Y-D.Z., Z-J.Y., H.C., Y-X.Z., and X-S.L. analyzed the data. M-A.H, X-N.W., H-W.J., H-N.Z., H.Q., and S-J.G. took responsibility for the accuracy of the data analysis. X-L.F., Q.L., and C-Z.Y. wrote the manuscript with suggestions from other authors.

Conflict of Interest Disclosures: The authors declare no conflicts of interest.

Funding/Support: This work was supported by grants from Wuhan Bureau of Science and Technology (No. 2020020601012218) and the Fundamental Research Funds for the Central Universities (HUST COVID-19 Rapid Response Call No. 2020kfyXGYJ040). 


\section{References}

1. Zhu, N., et al. A Novel Coronavirus from Patients with Pneumonia in China, 2019. N Engl $J$ Med 382, 727-733 (2020).

2. WHO. Coronavirus disease (COVID-2019) situation reports. 2020; Available at: https://www.who.int/emergencies/diseases/novel-coronavirus-2019/situation-reports. Accessed 20 June, 2020.

3. Sempowski, G.D., Saunders, K.O., Acharya, P., Wiehe, K.J. \& Haynes, B.F. Pandemic Preparedness: Developing Vaccines and Therapeutic Antibodies For COVID-19. Cell 181, 1458-1463 (2020).

4. Wiersinga, W.J., Rhodes, A., Cheng, A.C., Peacock, S.J. \& Prescott, H.C. Pathophysiology, Transmission, Diagnosis, and Treatment of Coronavirus Disease 2019 (COVID-19): A Review. JAMA (2020).

5. Dhama, K. \& Khan, S. Coronavirus Disease 2019-COVID-19. Clin Microbiol Rev 33(2020).

6. Widge, A.T., Rouphael, N.G. \& Jackson, L.A. Durability of Responses after SARS-CoV-2 mRNA-1273 Vaccination. $N$ Engl J Med (2020).

7. Polack, F.P., et al. Safety and Efficacy of the BNT162b2 mRNA Covid-19 Vaccine. $N$ Engl $J$ Med (2020).

8. Voysey, M., et al. Safety and efficacy of the ChAdOx1 nCoV-19 vaccine (AZD1222) against SARS-CoV-2: an interim analysis of four randomised controlled trials in Brazil, South Africa, and the UK. Lancet (2020).

9. USA Today. Alaska woman has allergic reaction to COVID vaccine. 2020; Available at: https://www.usatoday.com/videos/news/nation/2020/12/17/alaska-woman-has-allergicreaction-covid-vaccine/3934493001/. Accessed 24 December, 2020.

10. USA Today. 'Very inconsistent': 2 allergic reactions in the UK to COVID-19 vaccine puzzle researchers. 2020; Available at: https://www.usatoday.com/story/news/health/2020/12/09/covid-pfizer-vaccine-allergicreaction-

$\underline{\mathrm{uk} / 6505867002 / ? \mathrm{utm} \text { source}=\text { feedblitz\&utm medium=FeedBlitzRss\&utm campaign }=\mathrm{us}}$ atoday-newstopstories. Accessed 24 December, 2020.

11. Lee, W.S. \& Wheatley, A.K. Antibody-dependent enhancement and SARS-CoV-2 vaccines and therapies. Nat Microbiol 5, 1185-1191 (2020).

12. Halstead, S.B. \& Katzelnick, L. COVID-19 Vaccines: Should We Fear ADE? J Infect Dis 222, 1946-1950 (2020).

13. Wu, A., et al. Genome Composition and Divergence of the Novel Coronavirus (2019-nCoV) Originating in China. Cell Host Microbe 27, 325-328 (2020).

14. Walls, A.C., et al. Structure, Function, and Antigenicity of the SARS-CoV-2 Spike Glycoprotein. Cell 181, 281-292.e286 (2020).

15. Wu, J., et al. SARS-CoV-2 infection induces sustained humoral immune responses in convalescent patients following symptomatic COVID-19. 2020.2007.2021.20159178 (medRxiv, 2020).

16. Vogelzang, E.H., et al. Development of a SARS-CoV-2 total antibody assay and the dynamics of antibody response over time in hospitalized and non-hospitalized patients with COVID-19. 2020.2006.2017.20133793 (medRxiv, 2020).

17. Li, K., et al. The Dynamic Changes of Antibodies against SARS-CoV-2 during the Infection and Recovery of COVID-19. 2020.2005.2018.20105155 (medRxiv, 2020).

18. Lei, Q., et al. Antibody dynamics to SARS-CoV-2 in asymptomatic COVID-19 infections. in medRxiv 2020.2007.2009.20149633 (2020).

19. Lynch, K.L., et al. Magnitude and kinetics of anti-SARS-CoV-2 antibody responses and their relationship to disease severity. Clin Infect Dis (2020).

20. Zhang, S., et al. Autoantibody signature in hepatocellular carcinoma using seromics. $J$ Hematol Oncol 13, 85 (2020).

21. Yang, L., et al. Identification of Serum Biomarkers for Gastric Cancer Diagnosis Using a Human Proteome Microarray. Mol Cell Proteomics 15, 614-623 (2016).

22. Deng, J., et al. Mycobacterium tuberculosis proteome microarray for global studies of protein function and immunogenicity. Cell Rep 9, 2317-2329 (2014).

23. Jiang, H., et al. SARS-CoV-2 proteome microarray for global profiling of COVID-19 
24. specific IgG and IgM responses. Nature communications 11, 3581 (2020).

24. Government of the People's Republic of China. New coronavirus pneumonia diagnosis and treatment plan (Fifth Edition). 2020; Available at: http://www.nhc.gov.cn/yzygj/s7653p/202002/d4b895337e19445f8d728fcaf1e3e13a.shtml. Accessed May 18, 2020.

25. Chen, T., et al. Clinical characteristics of 113 deceased patients with coronavirus disease 2019: retrospective study. BMJ 368, m1091 (2020).

26. Zhou, F., et al. Clinical course and risk factors for mortality of adult inpatients with COVID-19 in Wuhan, China: a retrospective cohort study. Lancet 395, 1054-1062 (2020).

27. Yu, C., et al. Clinical Characteristics, Associated Factors, and Predicting COVID-19 Mortality Risk: A Retrospective Study in Wuhan, China. Am J Prev Med 59, 168-175 (2020).

28. Subissi, L., et al. One severe acute respiratory syndrome coronavirus protein complex integrates processive RNA polymerase and exonuclease activities. Proc Natl Acad Sci U S A 111, E3900-3909 (2014).

29. Yan, G., Liming, Y., Yucen, H., Fengjiang, L. \& Zihe, R. Structure of the RNA-dependent RNA polymerase from COVID-19 virus. Science 368, eabb7498 (2020).

30. Kirchdoerfer, R.N. \& Ward, A.B. Structure of the SARS-CoV nsp12 polymerase bound to nsp7 and nsp8 co-factors. Nat Commun 10, 2342 (2019).

31. Jauregui, A.R., Savalia, D., Lowry, V.K., Farrell, C.M. \& Wathelet, M.G. Identification of residues of SARS-CoV nsp1 that differentially affect inhibition of gene expression and antiviral signaling. PLoS One 8, e62416 (2013).

32. Angelini, M.M., Akhlaghpour, M., Neuman, B.W. \& Buchmeier, M.J. Severe acute respiratory syndrome coronavirus nonstructural proteins 3, 4, and 6 induce doublemembrane vesicles. mBio 4(2013).

33. Miknis, Z.J., et al. Severe acute respiratory syndrome coronavirus nsp9 dimerization is essential for efficient viral growth. J Virol 83, 3007-3018 (2009).

34. Snijder, E.J., Decroly, E. \& Ziebuhr, J. The Nonstructural Proteins Directing Coronavirus RNA Synthesis and Processing. Adv Virus Res 96, 59-126 (2016).

35. Bouvet, M., et al. In vitro reconstitution of SARS-coronavirus mRNA cap methylation. PLoS Pathog 6, e1000863 (2010).

36. Bouvet, M., et al. RNA 3'-end mismatch excision by the severe acute respiratory syndrome coronavirus nonstructural protein nsp10/nsp14 exoribonuclease complex. Proc Natl Acad Sci U S A 109, 9372-9377 (2012).

37. Liu, S.T.H., et al. Convalescent plasma treatment of severe COVID-19: a propensity scorematched control study. Nat Med 26, 1708-1713 (2020).

38. Shen, C., et al. Treatment of 5 Critically Ill Patients With COVID-19 With Convalescent Plasma. JAMA 323, 1582-1589 (2020).

39. Pathak, E.B. Convalescent plasma is ineffective for covid-19. Bmj 371, m4072 (2020).

40. Simonovich, V.A., et al. A Randomized Trial of Convalescent Plasma in Covid-19 Severe Pneumonia. N Engl J Med (2020).

41. Li, L., et al. Effect of Convalescent Plasma Therapy on Time to Clinical Improvement in Patients With Severe and Life-threatening COVID-19: A Randomized Clinical Trial. JAMA 324, 1-11 (2020). 
Table 1. Baseline characteristics of participated COVID-19 patients

\begin{tabular}{|c|c|c|c|c|}
\hline & All patients & Survivors & Nonsurvivors & $p$ value \\
\hline $\mathrm{N}$ & 1034 & 955 & 79 & \\
\hline Age, median (IQR), years & $63(51-71)$ & $62(51-70)$ & $68(59-78)$ & $<0.001$ \\
\hline Female, $\mathrm{n}(\%)$ & $524(50.7)$ & $491(51.4)$ & $33(41.8)$ & 0.10 \\
\hline Time from onset to admission, Median (IQR), days & $13(8-21)$ & $13(8-22)$ & $11(5-19)$ & 0.03 \\
\hline Length of hospital stay, Median (IQR), days & $24(15-35)$ & $25(16-35)$ & $18(9-26)$ & $<0.001$ \\
\hline Time from onset to outcome, Median (IQR), days & $40(33-52)$ & $41(33-52)$ & $32(25-39)$ & $<0.001$ \\
\hline \multicolumn{5}{|l|}{ Comorbidity, $\mathrm{n}(\%)$} \\
\hline Hypertension & $383(37.0)$ & $355(37.2)$ & $28(35.4)$ & 0.76 \\
\hline Diabetes & $191(18.5)$ & $173(18.1)$ & $18(22.8)$ & 0.30 \\
\hline Coronary heart disease & $68(6.6)$ & $57(6.0)$ & $11(13.9)$ & 0.006 \\
\hline Chronic obstructive pulmonary disease & $6(0.6)$ & $3(0.3)$ & $3(3.8)$ & 0.007 \\
\hline Cerebrovascular disease & $44(4.3)$ & $37(3.9)$ & $7(8.9)$ & 0.07 \\
\hline Chronic liver disease & $21(2.0)$ & $19(2.0)$ & $2(2.5)$ & 0.67 \\
\hline Chronic renal disease & $23(2.2)$ & $20(2.1)$ & $3(3.8)$ & 0.41 \\
\hline Cancer & $45(4.4)$ & $35(3.7)$ & $10(12.7)$ & 0.001 \\
\hline \multicolumn{5}{|l|}{ Laboratory results, n (\%) } \\
\hline Lymphopenia, $<1.1 \times 10^{\wedge} 9 / \mathrm{L}$ & $294(30.7)$ & $234(26.4)$ & $60(83.3)$ & $<0.001$ \\
\hline Neutrophilia, $\geq 6.3 \times 10^{\wedge} 9 / \mathrm{L}$ & 181(18.9) & $125(14.1)$ & $56(77.8)$ & $<0.001$ \\
\hline Thrombocytopenia, $\geq 350 \times 10^{\wedge} 9 / \mathrm{L}$ & $64(6.7)$ & $62(7.0)$ & $2(2.7)$ & 0.16 \\
\hline Leukocytosis, $\geq 9.5 \times 10^{\wedge} 9 / \mathrm{L}$ & $146(15.2)$ & $98(11.1)$ & $48(65.8)$ & $<0.001$ \\
\hline Increased lactate dehydrogenase, $\geq 214 \mathrm{U} / \mathrm{L}$ & $405(43.0)$ & $342(39.3)$ & $63(88.7)$ & $<0.001$ \\
\hline Increased alanine aminotransferase, $\geq 41 \mathrm{U} / \mathrm{L}$ & $239(25.4)$ & $217(24.9)$ & $22(31.0)$ & 0.26 \\
\hline Increased aspartate aminotransferase, $\geq 40 \mathrm{U} / \mathrm{L}$ & $129(13.7)$ & 101(11.6) & $28(40.0)$ & $<0.001$ \\
\hline Increased creatinine, $\geq 104 \mu \mathrm{mol} / \mathrm{L}$ & $57(6.3)$ & $39(4.7)$ & $18(26.1)$ & $<0.001$ \\
\hline Increased C-reactive protein, $\geq 3 \mathrm{mg} / \mathrm{L}$ & $330(45.9)$ & $289(42.7)$ & 41(97.6) & $<0.001$ \\
\hline Increased procalcitonin, $\geq 0.05 \mathrm{ng} / \mathrm{ml}$ & $159(29.3)$ & $122(24.3)$ & $37(92.5)$ & $<0.001$ \\
\hline Increased D-dimer, $\geq 0.5 \mathrm{mg} / \mathrm{L}$ & $361(59.4)$ & $302(55.1)$ & $59(98.3)$ & $<0.001$ \\
\hline Increased IL2R, > $710 \mathrm{U} / \mathrm{mL}$ & $67(16.2)$ & $57(14.4)$ & $10(55.6)$ & $<0.001$ \\
\hline Increased IL6, > $7 \mathrm{ng} / \mathrm{L}$ & $98(23.5)$ & $82(20.6)$ & $16(88.9)$ & $<0.001$ \\
\hline
\end{tabular}

Data were shown as medians (IQR) or number (\%), respectively. IQR, inter-quartile ranges. 
Table 2. Comparison of SARS-CoV-2 specific IgG responses ([log2(FI)]) between survivors and nonsurivivors

\begin{tabular}{|c|c|c|c|c|}
\hline Proteins & All & Survivors & Nonsurvivors & $p$ \\
\hline S1 & $13.9(13.0-14.4)$ & $13.9(13.0-14.4)$ & $13.6(12.0-14.6)$ & 0.30 \\
\hline S2 & 9.1(8.4-9.6) & 9.1(8.4-9.6) & 9.0(8.1-9.7) & 0.34 \\
\hline $\mathrm{N}$ & $10.3(9.2-11.1)$ & $10.3(9.2-11.2)$ & 9.8(7.9-10.6) & $<0.001$ \\
\hline N-Nter & $13.2(12.3-13.8)$ & $13.2(12.3-13.8)$ & 13.1(11.6-13.7) & 0.10 \\
\hline $\mathrm{N}-\mathrm{Cter}$ & $13.4(12.5-14.0)$ & $13.4(12.6-14.0)$ & $13.3(11.8-14.2)$ & 0.68 \\
\hline $\mathbf{E}$ & 5.5(4.6-6.8) & 5.5(4.6-6.8) & $5.8(4.9-7.6)$ & 0.04 \\
\hline NSP1 & 8.2(7.5-9.1) & 8.1(7.4-9.0) & $9.0(8.4-9.6)$ & $<0.001$ \\
\hline NSP2 & $6.6(5.6-7.8)$ & $6.5(5.6-7.7)$ & 7.1(6.0-8.2) & 0.01 \\
\hline NSP4 & 7.9(7.4-8.7) & 7.9(7.3-8.7) & 8.2(7.8-9.4) & $<0.001$ \\
\hline NSP5 & 5.5(4.9-6.2) & $5.5(4.9-6.2)$ & $5.8(5.1-6.7)$ & 0.01 \\
\hline NSP7 & $9.4(8.8-10.0)$ & 9.4(8.8-10.0) & $9.9(9.6-10.4)$ & $<0.001$ \\
\hline NSP8 & $7.8(6.8-9.0)$ & 7.6(6.7-8.9) & 8.8(8.0-9.2) & $<0.001$ \\
\hline NSP9 & $8.7(8.0-9.5)$ & $8.7(8.0-9.5)$ & $9.4(8.6-9.8)$ & $<0.001$ \\
\hline NSP10 & $6.3(5.3-7.6)$ & $6.2(5.3-7.4)$ & $7.2(6.5-8.0)$ & $<0.001$ \\
\hline RdRp & 8.1(7.4-9.3) & 8.0(7.4-9.2) & $9.2(8.5-9.6)$ & $<0.001$ \\
\hline NSP14 & $7.4(6.7-8.4)$ & $7.3(6.6-8.3)$ & $8.3(7.7-9.1)$ & $<0.001$ \\
\hline NSP15 & 7.1(6.2-8.4) & 7.1(6.1-8.3) & 7.7(6.6-9.1) & 0.02 \\
\hline NSP16 & 7.1(6.3-8.2) & $7.0(6.3-8.2)$ & 7.7(6.6-8.9) & 0.004 \\
\hline ORF3a & $5.2(4.0-6.6)$ & $5.3(4.0-6.6)$ & $4.6(3.4-5.7)$ & 0.001 \\
\hline ORF3b & $8.7(8.0-9.6)$ & $8.6(8.0-9.6)$ & $9.6(9.1-9.9)$ & $<0.001$ \\
\hline ORF6 & $3.7(0.0-4.9)$ & $3.7(0.0-4.9)$ & $3.4(0.0-4.7)$ & 0.30 \\
\hline ORF7b & $6.4(5.4-7.2)$ & $6.4(5.5-7.2)$ & $5.6(4.8-6.8)$ & $<0.001$ \\
\hline ORF9b & $8.0(7.5-8.8)$ & $8.0(7.4-8.7)$ & $8.4(7.9-9.5)$ & $<0.001$ \\
\hline
\end{tabular}


medRxiv preprint doi: https://doi.org/10.1101/2020.11.10.20228890; this version posted May 8,2021 . The copyright holder for this preprint (which was not certified by peer review) is the author/funder, who has granted medRxiv a license to display the preprint in perpetuity.

All rights reserved. No reuse allowed without permission.

Table 3. Hazard ratio (95\% CI) for COVID-19 mortality according to tertiles of anti-SARS-CoV-2 specific IgG responses

\begin{tabular}{|c|c|c|c|c|c|}
\hline \multirow{2}{*}{ Proteins } & \multirow{2}{*}{ Model } & \multicolumn{3}{|c|}{ Tertile of proteins $\left[\log _{2}(\mathrm{FI})\right]$} & \multirow{2}{*}{$p$ trend } \\
\hline & & T1 & $\mathbf{T} 2$ & T3 & \\
\hline \multirow{2}{*}{$\mathrm{N}$} & Model 1 & 1 & $0.63(0.38-1.05)$ & $0.40(0.22-0.73)$ & 0.002 \\
\hline & Model 2 & 1 & $0.79(0.46-1.34)$ & $0.73(0.39-1.37)$ & 0.52 \\
\hline \multirow{2}{*}{$\mathrm{E}$} & Model 1 & 1 & $1.07(0.59-1.92)$ & $1.25(0.72-2.20)$ & 0.41 \\
\hline & Model 2 & 1 & $1.11(0.59-2.09)$ & $1.25(0.68-2.29)$ & 0.56 \\
\hline \multirow{2}{*}{ NSP1 } & Model 1 & 1 & $3.05(1.38-6.71)$ & $3.76(1.77-8.03)$ & 0.0006 \\
\hline & Model 2 & 1 & $2.84(1.21-6.63)$ & $3.10(1.38-6.99)$ & 0.02 \\
\hline \multirow{2}{*}{ NSP2 } & Model 1 & 1 & $0.96(0.53-1.75)$ & $1.30(0.75-2.26)$ & 0.3 \\
\hline & Model 2 & 1 & $0.76(0.39-1.45)$ & $1.18(0.66-2.11)$ & 0.64 \\
\hline \multirow{2}{*}{ NSP4 } & Model 1 & 1 & $1.90(0.98-3.66)$ & $2.06(1.09-3.90)$ & 0.03 \\
\hline & Model 2 & 1 & 2.74(1.29-5.85) & $2.60(1.24-5.46)$ & $\mathbf{0 . 0 3}$ \\
\hline \multirow{2}{*}{ NSP5 } & Model 1 & 1 & $1.08(0.60-1.95)$ & $1.48(0.85-2.57)$ & 0.15 \\
\hline & Model 2 & 1 & $1.15(0.60-2.22)$ & $1.79(0.98-3.27)$ & 0.07 \\
\hline \multirow{2}{*}{ NSP7 } & Model 1 & 1 & $4.43(1.85-10.62)$ & $4.94(2.10-11.64)$ & 0.0003 \\
\hline & Model 2 & 1 & $4.01(1.52-10.53)$ & $4.28(1.67-10.98)$ & 0.008 \\
\hline \multirow{2}{*}{ NSP8 } & Model 1 & 1 & $2.71(1.23-5.98)$ & $3.91(1.84-8.32)$ & 0.0002 \\
\hline & Model 2 & 1 & $2.34(0.99-5.52)$ & $3.20(1.42-7.21)$ & 0.009 \\
\hline \multirow{2}{*}{ NSP9 } & Model 1 & 1 & $1.92(0.92-4.01)$ & $3.28(1.65-6.54)$ & 0.0003 \\
\hline & Model 2 & 1 & $1.40(0.64-3.07)$ & $2.69(1.29-5.61)$ & 0.005 \\
\hline \multirow{2}{*}{ NSP10 } & Model 1 & 1 & $3.55(1.46-8.59)$ & $5.36(2.28-12.60)$ & $<0.0001$ \\
\hline & Model 2 & 1 & $3.19(1.22-8.38)$ & $4.89(1.92-12.46)$ & 0.0005 \\
\hline \multirow{2}{*}{ RdRp } & Model 1 & 1 & $2.17(1.00-4.69)$ & $3.57(1.74-7.32)$ & 0.0002 \\
\hline & Model 2 & 1 & $2.31(1.02-5.20)$ & $2.80(1.30-6.02)$ & 0.02 \\
\hline \multirow{2}{*}{ NSP14 } & Model 1 & 1 & $1.75(0.79-3.85)$ & $3.49(1.70-7.14)$ & 0.0001 \\
\hline & Model 2 & 1 & $1.37(0.59-3.19)$ & $2.65(1.23-5.71)$ & 0.007 \\
\hline \multirow{2}{*}{ NSP15 } & Model 1 & 1 & $1.03(0.56-1.90)$ & $1.40(0.80-2.45)$ & 0.2 \\
\hline & Model 2 & 1 & $0.85(0.44-1.65)$ & $1.23(0.68-2.22)$ & 0.49 \\
\hline \multirow{2}{*}{ NSP16 } & Model 1 & 1 & $0.91(0.49-1.70)$ & $1.52(0.87-2.64)$ & 0.09 \\
\hline & Model 2 & 1 & $0.71(0.36-1.39)$ & $1.40(0.78-2.50)$ & 0.28 \\
\hline \multirow{2}{*}{ ORF3a } & Model 1 & 1 & $1.03(0.63-1.68)$ & $0.50(0.27-0.92)$ & 0.04 \\
\hline & Model 2 & 1 & $1.35(0.79-2.29)$ & $0.69(0.35-1.33)$ & 0.53 \\
\hline \multirow{2}{*}{ ORF3b } & Model 1 & 1 & $1.63(0.77-3.43)$ & $3.20(1.66-6.17)$ & 0.0001 \\
\hline & Model 2 & 1 & $1.68(0.76-3.70)$ & $2.69(1.34-5.38)$ & 0.02 \\
\hline \multirow{2}{*}{ ORF7b } & Model 1 & 1 & $0.60(0.35-1.03)$ & $0.45(0.26-0.81)$ & 0.005 \\
\hline & Model 2 & 1 & $0.79(0.45-1.39)$ & $0.71(0.39-1.30)$ & 0.2 \\
\hline \multirow{2}{*}{ ORF9b } & Model 1 & 1 & $1.66(0.87-3.15)$ & $2.02(1.11-3.68)$ & 0.02 \\
\hline & Model 2 & 1 & $1.72(0.86-3.43)$ & $2.11(1.11-4.04)$ & 0.03 \\
\hline
\end{tabular}

Model 1: Adjusted for age and sex.

Model 2: Additional adjustment for hypertension, diabetes, lymphopenia, increased alanine aminotransferase, and increased lactate dehydrogenase.

FI: Fluorescence Intensity. 
Table 4. Hazard ratio (95\% CI) for COVID-19 mortality according to tertiles of principal components of anti-SARS-CoV-2 specific IgG responses

\begin{tabular}{lcccc}
\hline \multirow{2}{*}{ Proteins } & \multicolumn{3}{c}{ Tertile of principal components } & \multirow{2}{*}{$\boldsymbol{p}$ trend } \\
\cline { 2 - 4 } & T1 & T2 & T3 & \\
\hline PC1 & & & & \\
Model 1 & 1.00 & $2.17(1.05-4.51)$ & $2.79(1.40-5.59)$ & $\mathbf{0 . 0 0 4}$ \\
Model 2 & 1.00 & $1.66(0.76-3.65)$ & $2.24(1.07-4.68)$ & $\mathbf{0 . 0 3}$ \\
PC2 & & & & \\
Model 1 & 1.00 & $0.70(0.43-1.13)$ & $0.31(0.16-0.61)$ & $<0.001$ \\
$\quad$ Model 2 & 1.00 & $0.89(0.53-1.51)$ & $0.62(0.31-1.25)$ & 0.20 \\
PC3 & & & & \\
Model 1 & 1.00 & $0.69(0.42-1.14)$ & $0.48(0.26-0.88)$ & 0.01 \\
Model 2 & 1.00 & $0.82(0.47-1.41)$ & $0.72(0.38-1.39)$ & 0.30 \\
PC4 & & & & \\
Model 1 & 1.00 & $0.70(0.40-1.21)$ & $0.98(0.59-1.65)$ & 0.91 \\
Model 2 & 1.00 & $0.94(0.52-1.72)$ & $1.24(0.71-2.16)$ & 0.47 \\
\hline
\end{tabular}

PC: principal component. The main contributors are NSP1, NSP2, NSP4, NSP7, NSP8, NSP9, NSP10, RdRp, NSP14, NSP15, NSP16, ORF3b, and ORF9b for PC1; S1, N, N-Nter, and N-Cter for PC2; ORF7b for PC3.

Model 1: Adjusted for age and sex.

Model 2: Additional adjustment for hypertension, diabetes, lymphopenia, increased alanine aminotransferase, and increased lactate dehydrogenase. 
medRxiv preprint doi: https://doi.org/10.1101/2020.11.10.20228890; this version posted May 8,2021 . The copyright holder for this preprint (which was not certified by peer review) is the author/funder, who has granted medRxiv a license to display the preprint in perpetuity.

All rights reserved. No reuse allowed without permission.

Table 5. Factor loadings of 20 proteins of anti-SARS-CoV-2 specific IgG responses among the study participants

\begin{tabular}{|c|c|c|c|c|}
\hline Variables & PC1 & $\mathrm{PC} 2$ & PC3 & $\mathrm{PC} 4$ \\
\hline $\mathrm{S} 1$ & 0.26 & 0.87 & -0.15 & -0.06 \\
\hline $\mathrm{S} 2$ & 0.36 & 0.59 & -0.05 & 0.27 \\
\hline $\mathrm{N}$ & 0.15 & 0.87 & 0.07 & -0.07 \\
\hline N-Nter & 0.26 & 0.90 & -0.08 & -0.07 \\
\hline N-Cter & 0.39 & 0.83 & -0.12 & -0.08 \\
\hline $\mathrm{E}$ & 0.67 & -0.07 & 0.45 & -0.29 \\
\hline NSP1 & 0.87 & -0.13 & -0.13 & 0.09 \\
\hline NSP2 & 0.78 & -0.04 & 0.27 & -0.17 \\
\hline NSP4 & 0.87 & -0.10 & -0.06 & 0.11 \\
\hline NSP5 & 0.65 & 0.01 & 0.49 & -0.12 \\
\hline NSP7 & 0.78 & -0.05 & -0.18 & 0.14 \\
\hline NSP8 & 0.79 & -0.16 & -0.21 & 0.13 \\
\hline NSP9 & 0.72 & -0.13 & -0.22 & 0.25 \\
\hline NSP10 & 0.77 & -0.19 & -0.28 & 0.19 \\
\hline $\mathrm{RdRp}$ & 0.81 & -0.12 & -0.21 & 0.00 \\
\hline NSP14 & 0.89 & -0.05 & 0.07 & -0.20 \\
\hline NSP15 & 0.78 & -0.09 & 0.15 & -0.17 \\
\hline NSP16 & 0.81 & -0.04 & 0.29 & -0.21 \\
\hline ORF3a & -0.20 & 0.29 & 0.50 & 0.47 \\
\hline ORF3b & 0.85 & -0.13 & -0.13 & 0.09 \\
\hline ORF6 & 0.17 & 0.04 & 0.23 & 0.67 \\
\hline ORF7b & 0.18 & -0.02 & 0.72 & 0.19 \\
\hline ORF9b & 0.78 & -0.05 & -0.10 & 0.03 \\
\hline Eigen values & 9.95 & 3.609 & 1.79 & 1.198 \\
\hline Total variance $(\%)$ & 43.263 & 15.691 & 7.784 & 5.207 \\
\hline Cumulative variance $(\%)$ & 43.263 & 58.954 & 66.737 & 71.945 \\
\hline
\end{tabular}

Bold values denote factor loading $>0.7$ are deemed to be statistically significant. 
Table 6. Correlations between the levels of anti-SARS-CoV-2 specific IgG responses and other laboratory biomarkers related with severity factors

\begin{tabular}{|c|c|c|c|c|c|c|c|}
\hline & PCT & CRP & LYMPH & LDH & $\mathrm{DD}$ & IL-2R & IL-6 \\
\hline \multicolumn{8}{|l|}{ NSP1_IgG } \\
\hline$r_{s}$ & $0.19^{* *}$ & $0.21^{* *}$ & $-0.16^{* *}$ & $0.17^{* *}$ & $0.31^{* *}$ & $0.18^{* *}$ & 0.09 \\
\hline \multicolumn{8}{|l|}{ NSP4_IgG } \\
\hline $\mathrm{r}_{\mathrm{s}}$ & $0.09^{*}$ & $0.14^{* *}$ & $-0.09^{* *}$ & $0.10^{* *}$ & $0.21^{* *}$ & $0.10^{*}$ & 0.02 \\
\hline \multicolumn{8}{|l|}{ NSP7_IgG } \\
\hline $\mathrm{r}_{\mathrm{s}}$ & $0.19^{* *}$ & $0.22^{* *}$ & $-0.17^{* *}$ & $0.19^{* * *}$ & $0.31^{* *}$ & $0.14^{* *}$ & 0.08 \\
\hline \multicolumn{8}{|l|}{ NSP8_IgG } \\
\hline $\mathrm{r}_{\mathrm{s}}$ & $0.12^{* *}$ & $0.19^{* *}$ & $-0.15^{* *}$ & $0.16^{* * *}$ & $0.31^{* *}$ & $0.11^{*}$ & $0.12^{*}$ \\
\hline \multicolumn{8}{|l|}{ NSP9_IgG } \\
\hline $\mathrm{r}_{\mathrm{s}}$ & $0.12^{* *}$ & $0.17^{* *}$ & $-0.09^{* *}$ & $0.12^{* *}$ & $0.17^{* *}$ & 0.07 & 0.07 \\
\hline \multicolumn{8}{|l|}{ NSP10_IgG } \\
\hline $\mathrm{r}_{\mathrm{s}}$ & $0.12^{* *}$ & $0.21^{* *}$ & $-0.15^{* *}$ & $0.15^{* *}$ & $0.31^{* *}$ & $0.16^{* *}$ & $0.13^{* *}$ \\
\hline \multicolumn{8}{|l|}{ RdRp_IgG } \\
\hline $\mathrm{r}_{\mathrm{s}}$ & $0.17^{* *}$ & $0.19^{* *}$ & $-0.15^{* *}$ & $0.14^{* *}$ & $0.31^{* *}$ & $0.13^{* *}$ & $0.11^{*}$ \\
\hline \multicolumn{8}{|l|}{ NSP14_IgG } \\
\hline $\mathrm{r}_{\mathrm{s}}$ & $0.15^{* *}$ & $0.17^{* *}$ & $-0.15^{* *}$ & $0.16^{* *}$ & $0.27^{* *}$ & $0.17^{* *}$ & $0.11^{*}$ \\
\hline \multicolumn{8}{|l|}{ ORF3b_IgG } \\
\hline $\mathrm{r}_{\mathrm{s}}$ & $0.15^{* *}$ & $0.18^{* *}$ & $-0.14^{* *}$ & $0.16^{* *}$ & $0.29^{* *}$ & $0.12^{*}$ & 0.06 \\
\hline \multicolumn{8}{|l|}{ ORF9b_IgG } \\
\hline $\mathrm{r}_{\mathrm{s}}$ & $0.12^{* *}$ & $0.12^{* *}$ & $-0.07^{*}$ & $0.11^{* *}$ & $0.19^{* *}$ & 0.04 & 0.01 \\
\hline
\end{tabular}

Spearman's rank correlation coefficients were shown in the table. $* p<0.05, * * p<0.01$. PCT: procalcitonin; CRP: C-reactive protein; LYMPH: lymphocyte count; LDH: lactate dehydrogenase; DD: D-dimer; IL-2R: interleukin-2 receptor; IL-6: interleukin-6. 

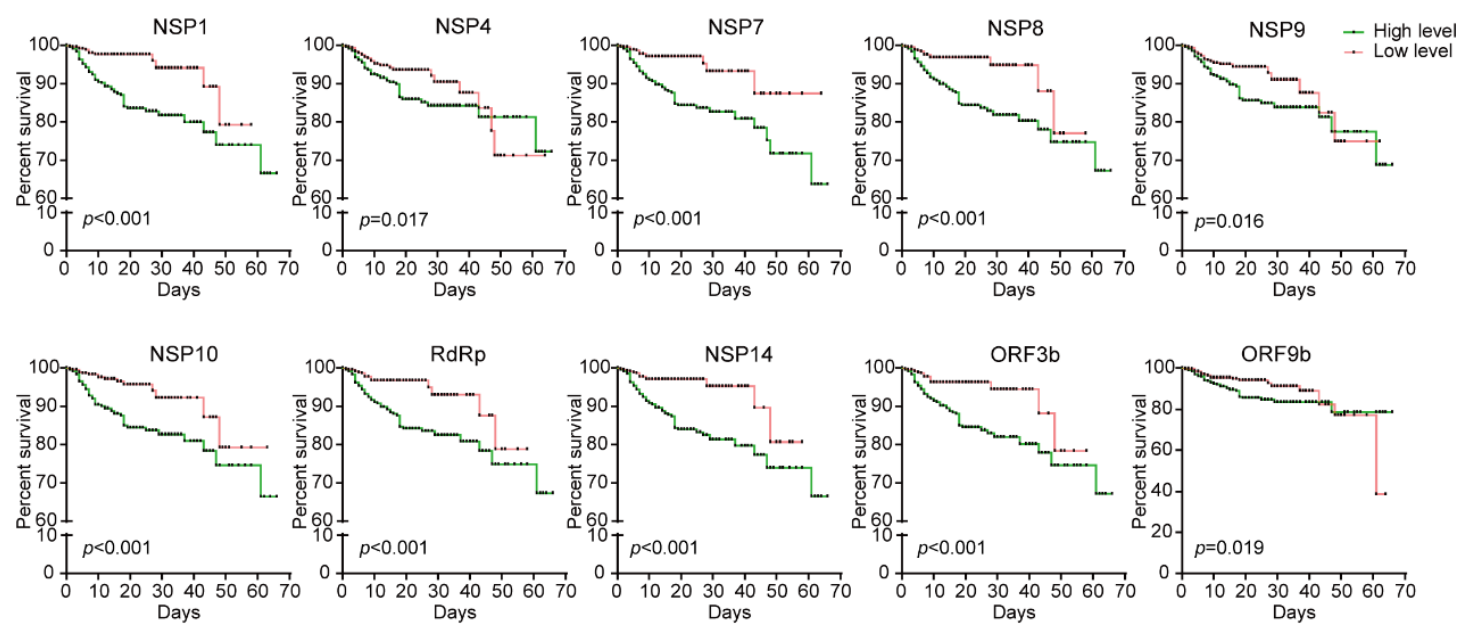

Figure 1. Kaplan-Meier survival curves of patients with high and low levels of IgG to 10 nonstructural/accessory proteins. Based on the median level of IgG responses to each protein, patients were classified as both high and low level groups after admission. Kaplan-Meier survival curves of patients with high (green) and low (red) levels of IgG antibodies to each protein, and Log-rank test was used to analyze the difference between two groups. 


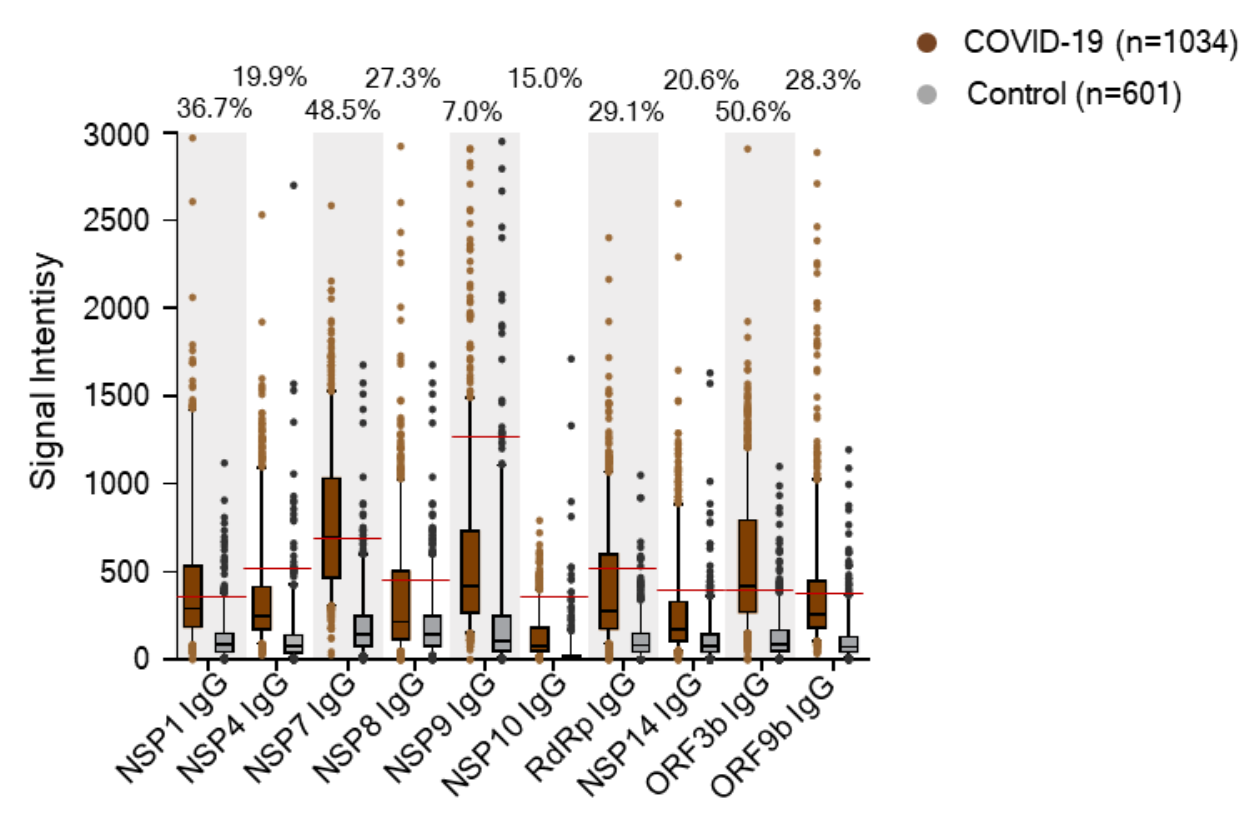

Figure 2. Comparison of signal intensities and positive rates of IgG antibodies between COVID-19 patients and healthy controls. IgG responses to 10 non-structural/accessory proteins were compared between 1,034 COVID-19 patients and 601 healthy serum controls. IgG responses were depicted as the boxplot according to the signal intensity of each serum sample on the proteome microarray. Data were represented by the median and 5th-95th percentile. The cut-off values of $\operatorname{IgG}$ antibody to each protein were set as mean +2 SD of the control group $(n=601)$ and shown as the red line. The positive rates of IgG antibodies to each protein in the patient groups were labeled on the figure. 
A
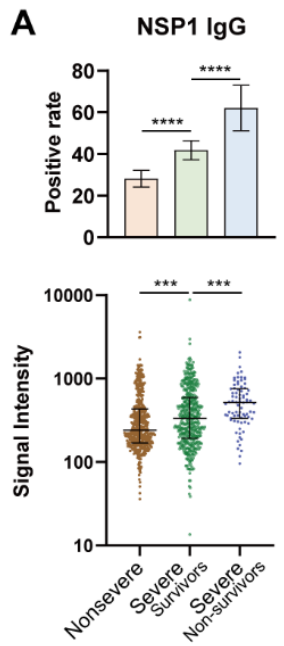

E
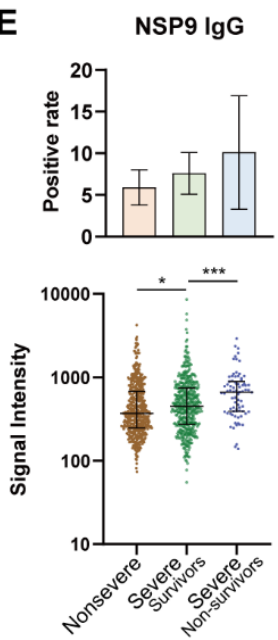

I
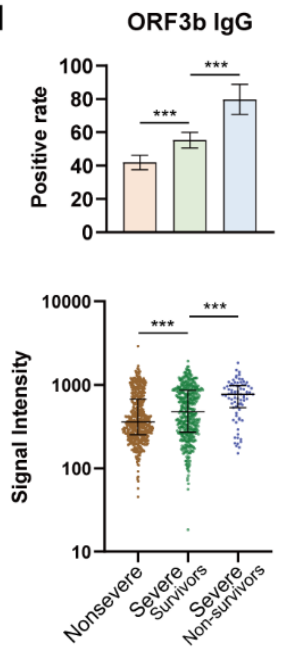
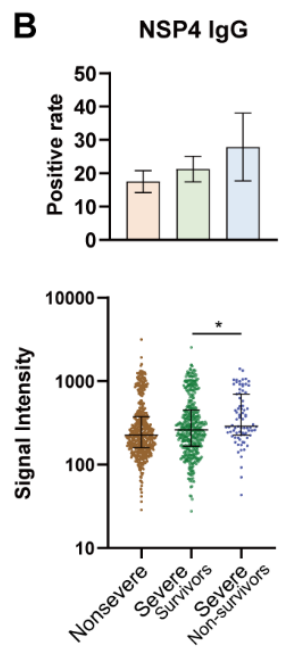

$\mathbf{F}$
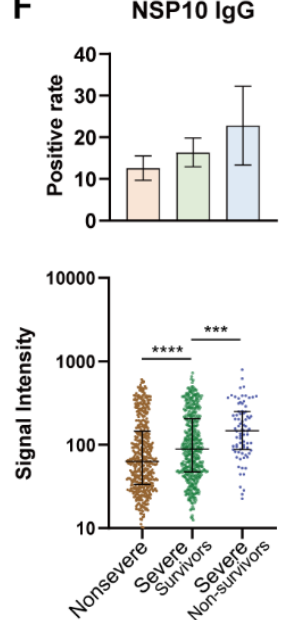

$\mathbf{J}$

ORF9b IgG
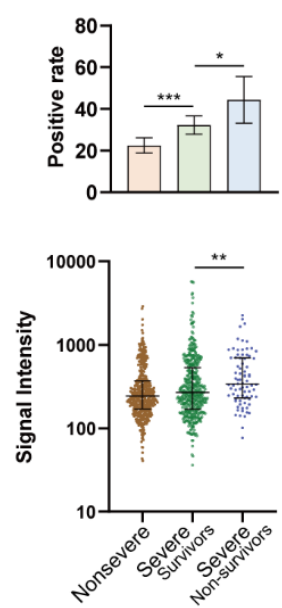
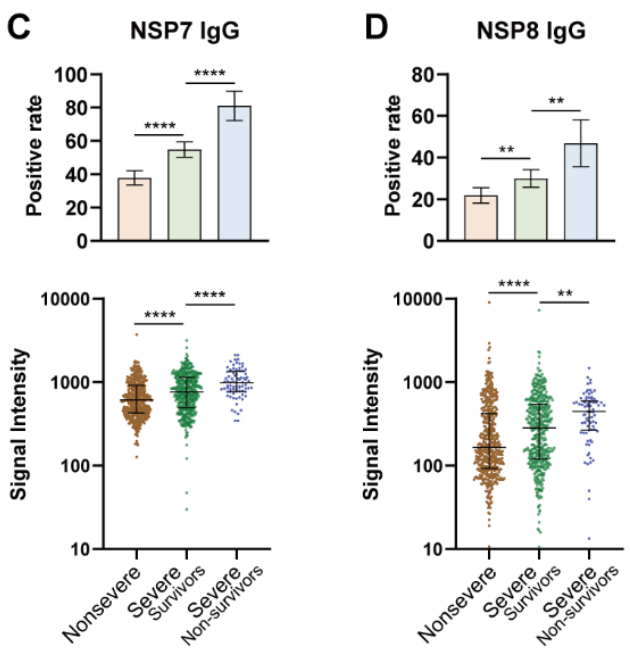

G $R d R p \lg G$

H NSP14 IgG
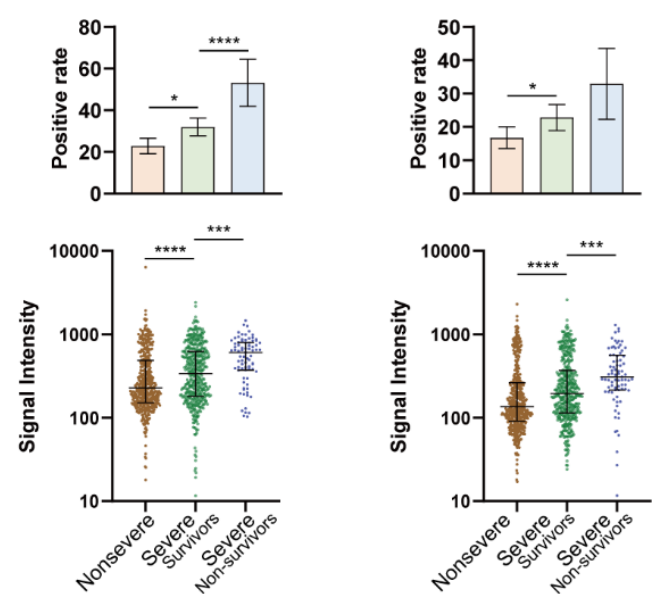

Figure 3. Comparison of IgG responses of 10 non-structural/accessory proteins among different severities of patients. 1,034 COVID-19 patients included in this study were divided into three groups: non-severe $(n=508)$, severe-survivors $(n=447)$, and severe-nonsurvivors $(n=79)$. Serum positive rate and signal intensity of IgG responses to NSP1 (A), NSP4 (B), NSP7 (C), NSP8 (D), NSP9 (E), NSP10 (F), RdRp (G), NSP14 (H), ORF3b (I), and ORF9b (J) were compared among different groups. For the positive rate analysis, error bar was given as the $95 \%$ confidential interval, and $\chi^{2}$ test was used to calculate $p$ values. For the signal intensity analysis, the middle line was set 
medRxiv preprint doi: https://doi.org/10.1101/2020.11.10.20228890; this version posted May 8, 2021. The copyright holder for this preprint (which was not certified by peer review) is the author/funder, who has granted medRxiv a license to display the preprint in perpetuity.

All rights reserved. No reuse allowed without permission.

as the median value; the upper and lower hinges were the values of $75 \%$ and $25 \%$ percentile, and Kruskale Wallis test and post-hoc test (Dunn-Bonferroni) were conducted to calculate $p$ values. ${ }^{*} p$ $<0.05, * * p<0.01, * * * p<0.001, * * * * p<0.0001$. 


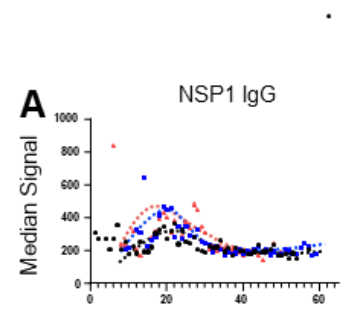

Days after symptom onset
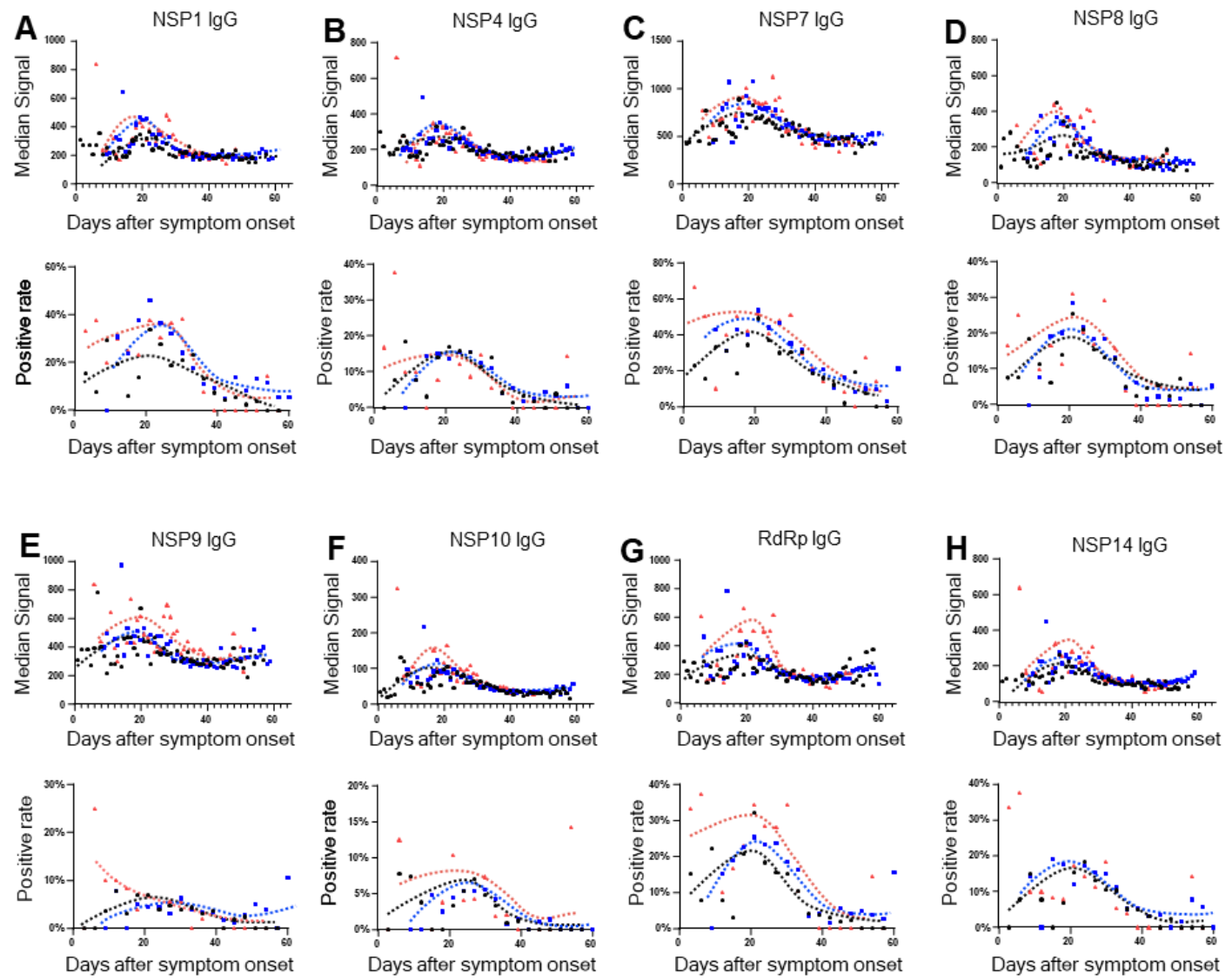
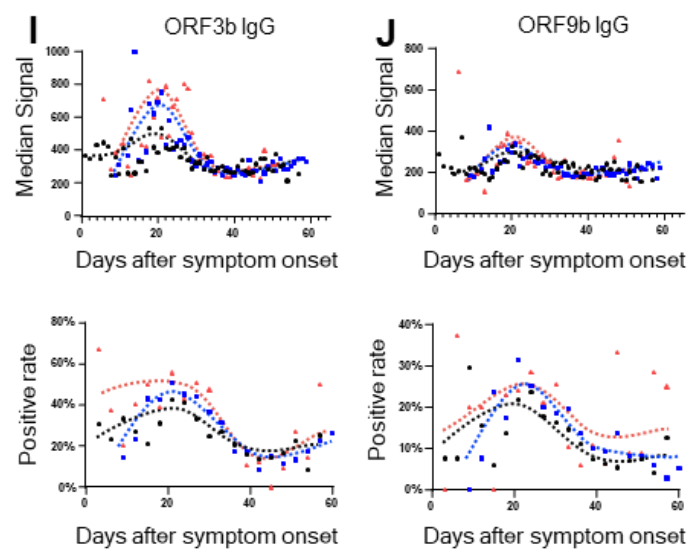

Figure 4. The dynamics of IgG responses to 10 non-structural/accessory proteins between different groups. 2,977 seral samples from 1,034 COVID-19 patients were used. The patients were divided into three groups: non-severe $(\mathrm{n}=508)$, severe-survivors $(\mathrm{n}=447)$, and severe-nonsurvivors $(\mathrm{n}=79)$. Signal intensity and serum positive rate of IgG responses to NSP1 (A), NSP4 (B), NSP7 (C), NSP8 (D), NSP9 (E), NSP10 (F), RdRp (G), NSP14 (H), ORF3b (I), and ORF9b (J) were compared among different groups. For signal intensity analysis, samples were grouped per day and the points with sample number less than 4 were excluded. For positive rate analysis, samples were grouped per three days. 
medRxiv preprint doi: https://doi.org/10.1101/2020.11.10.20228890; this version posted May 8, 2021. The copyright holder for this preprint (which was not certified by peer review) is the author/funder, who has granted medRxiv a license to display the preprint in perpetuity.

All rights reserved. No reuse allowed without permission.

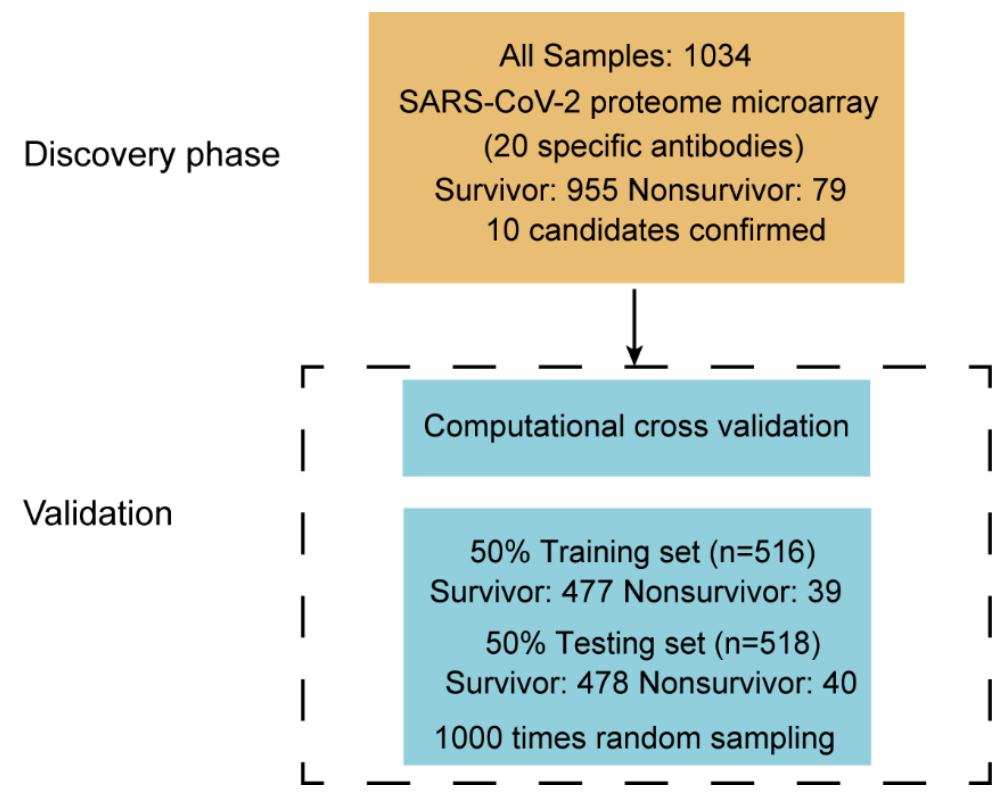

Figure 5. The workflow of validation 

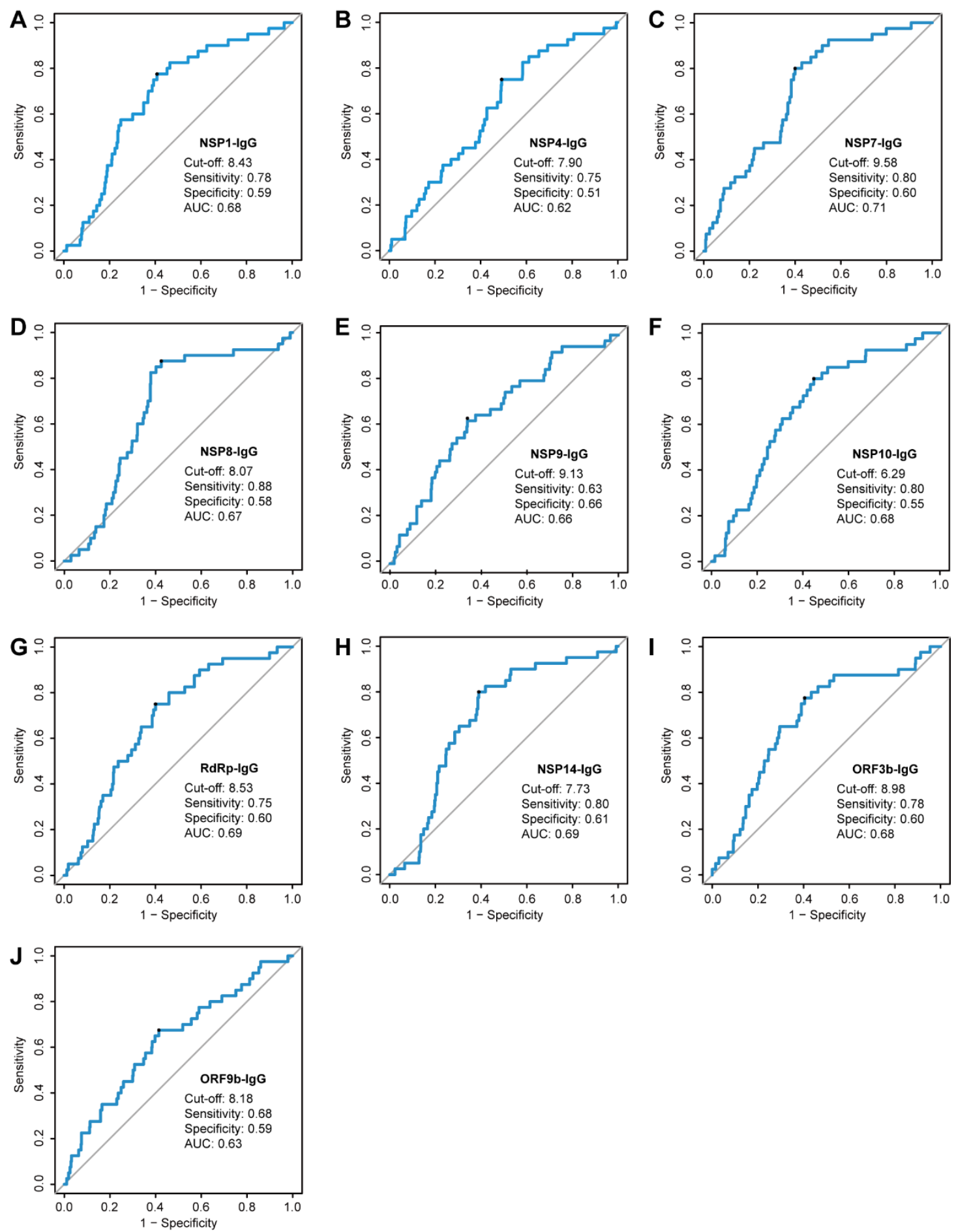

Figure 6. Computational cross-validations of IgG responses to 10 non-structural/accessory proteins for the prediction efficacy. The prediction efficacy was determined by a computational cross-validation. The receiver operating characteristic curve was conducted for the prediction of COVID-19 survival and death, and 1,000 times computational cross-validations were conducted. For each cross-validation procedure, 477 survivors and 39 non-survivors were randomly selected as the training set. The rest of the samples were treated as the testing set (478 survivors and 40 non-survivors). The average cutoff values were shown. 